\title{
The Influence of Different Commercial Probiotics on Biofloc Nutrition
}

\author{
Endang Dewi Masithah ${ }^{a^{*}}$, Fitri Anisha Kurniawati ${ }^{\mathrm{b}}$ and Azhar Muhammad Helmi ${ }^{\mathrm{b}}$ \\ aDepartment of Marine \\ Faculty of Fisheries and Marine, Airlangga University \\ Surabaya, East Java, Indonesia \\ *een_kica@yahoo.co.id \\ ${ }^{\mathbf{b}}$ Biotechnology Fisheries and Marine \\ Postgraduate School, Airlangga University \\ Surabaya, East Java, Indonesia
}

\begin{abstract}
The intensive aquaculture industry nowadays faces two major problems, such as the decrease of water quality caused by excess metabolite concentration and a lower utilization of natural feed in the high water circulation rate. Accumulation of organic material in the pond will increase population of bacteria. The process of decomposition of organic materials by aerobic bacteria will cause a decrease in the oxygen content in water. Therefore, the conversion of toxic ammonia to nitrate is highly useful and can be successfully accomplished through the implementation of biofloc technology and maximizing the contribution of natural feed in intensifying aquaculture technology. This study aims to gain information on nutrient composition of biofloc caused by the use of different commercial probiotics through the formation of biofloc, including probiotic $\mathrm{A}$, probiotic B and without probiotic. Parameters monitored in this research include biofloc nutrition (protein and fat) and other supporting parameters such as plakton diversity index, plankton domination index, $\mathrm{C}: \mathrm{N}$ ratio, $\mathrm{N}: \mathrm{P}$ ratio, $\mathrm{pH}$, temperature and dissolved oxygen. Data analysis was carried out by Anova (analysis of variance) and descriptive. This research demonstrated that different probiotics significantly affected the protein and fat content of biofloc. Probiotics containing different bacterium in wide variety can enrich biofloc nutrient.
\end{abstract}

Keywords- Bioflocs technology, Probiotics, C:N ratio, N:P ratio, biofloc nutrient

\section{INTRODUCTION}

The intensive aquaculture industry is currently facing a major problem caused by the decrease of water quality as a result of excess metabolite concentration. The abundance of organic matter in the fish pond will increase the bacterium population. Consequently, the organic matter in water will be decomposed by bacterium and cause the decrease of dissolved oxygen content. In order to convert toxic nitrogen, of which ammonia forms for controlling content in water, biofloc technology must be implemented [1].

On the other hand, fish aquaculture has close correlation with the increase of feed, the use of which can be a production factor in intensive aquaculture. One of less cost-consuming methods is biofloc technology which has been proven able to reduce about $60-70 \%$ of the total production cost [1]. Production of biofloc depends on the organic susbtrate load which can be carried out though the administration of probiotic. Selection of living bacterium is a crucial aspect to which researchers have paid attention because it can affect the concentration of $\mathrm{C}, \mathrm{N}$ and $\mathrm{P}$ atoms in water, whereby the $\mathrm{N}: \mathrm{P}$ and $\mathrm{C}: \mathrm{N}$ ratio determines the diversity and domination of living planktons. Meanwhile, plankton species and domination determines the nutrient content of biofloc biomass.

According to [2], microorganisms contained in probiotic can be used as inocula to increase useful bacteria population in water. Cellulotic fungi can digest the hydrogen bond of cellulose. Bacterium in probiotic can degrade glucose and fructose to produce energy. [3] states the use of a wide variety of probiotics will intensify the bioflucolation rate from the combination of bacterium and phytoplankton, which is highly valuable for shrimp and fish growth. Hence, the addition of probiotic will stimulate and enrich bacterium and plankton species in the biofloc.

According to the problem outlined above, study on the utilization of different commercial probiotics to determine its effect on phytoplaankton diversity and further biofloc nutrient formed was carried out. The nutritient content of biofloc will affect the quality of natural feed, which has function as feed subtitute to intensify the efficiency of intensive fish.

\section{EASE OF USE}

This study aims to gain information on nutrient composition of biofloc caused by the use of different commercial probiotics through the formation of biofloc, including probiotic $\mathrm{A}$, probiotic $\mathrm{B}$ and without probiotic.

Nutritional biofloc will determine the quality of the feed as a natural biofloc that serves as a substitution of artificial feed to increase the efficiency of intensive fish farming.

\section{MATERIALS AND METHODS}

\section{A. Materials and Methods}

Equipment used in this work were aquarium with the size of 40x20x35 $\mathrm{cm}^{3}$, Inhofe cone, aerator, stone aeration, aeration hose, $\mathrm{pH}$ meter, thermometer, DO kit, ammonia kit, hemocytometer and microscope. Materials used in the research are a commercial probiotic $\mathrm{A}$, commercial probiotic $\mathrm{B}$, molasses, fish pellet, ZA, bran, chlorine and dolomite. 


\section{B. Production of Biofloc}

Production of biofloc was carried out in 18 aquarium $\left(40 \times 20 \times 35 \mathrm{~cm}^{3}\right)$ filled with 20 liter of water. $0.1 \mathrm{~g}$ probiotic was inoculated per 20 liter of water to form biofloc. The aquarium was then filled with $84 \mathrm{~g}$ of mollases and ZA fertilizer for every five days [4] and $1 \mathrm{~kg}$ of bran. The mixture was then aerated and cultivated at the $\mathrm{pH}$ between $6.0-7.2$ survive and $\mathrm{N} / \mathrm{P}$ ratio in the range of 10-20. Approximately $20 \mathrm{mg} /$ liter of dolomite fertilizer was added to stabilize the $\mathrm{pH}$ [4].

\section{Sampling and plankton identification}

Floc growth in the culture media is indicated by color changes from clear to brown and then green and, finally, dark green [5]. The formed floc was then collected for further analysis.

\section{Determination of biofloc nutrient}

Biofloc nutrition content determination was performed through determining protein and fat content of biofloc by using AOAC 2007.

\section{RESULTS AND DISCUSSION}

\subsubsection{Protein and fat content of biofloc}

Protein and fat content of biofloc was obtained after floc formed on day 9 of the study. Protein content data can be seen in Table 1, while fat content data can be seen in Table 2.

Table 1. Protein content of biofloc produced in this present study

\begin{tabular}{|c|c|c|c|}
\hline \multirow{2}{*}{ Days } & \multicolumn{3}{|c|}{ Protein content (\%) } \\
\cline { 2 - 4 } & A & B & C \\
\hline 9 & $17.4^{\mathrm{b}} \pm 0.55$ & $18.0^{\mathrm{a}} \pm 0.44$ & $16.6^{\mathrm{c}} \pm 0.52$ \\
\hline 14 & $19.9^{\mathrm{b}} \pm 0.60$ & $20.8^{\mathrm{a}} \pm 0.31$ & $18.6^{\mathrm{c}} \pm 0.31$ \\
\hline 19 & $22.6^{\mathrm{b}} \pm 0.44$ & $24.5^{\mathrm{a}} \pm 0.62$ & $19.8^{\mathrm{c}} \pm 0.30$ \\
\hline 24 & $23.41^{\mathrm{b}} \pm 0.5$ & $25.59^{\mathrm{a}} \pm 0.52$ & $20.51^{\mathrm{c}} \pm 0.25$ \\
\hline
\end{tabular}

Table 2. Fat content of biofloc produced in this present study

\begin{tabular}{|c|c|c|c|}
\hline \multirow{2}{*}{ Days } & \multicolumn{3}{|c|}{ Fat content (\%) } \\
\cline { 2 - 4 } & A & B & C \\
\hline 9 & $0.59 \pm 0.11$ & $0.59 \pm 0.03$ & $0.59 \pm 0.10$ \\
\hline 14 & $1.19 \pm 0.12$ & $1.18 \pm 0.05$ & $1.31 \pm 0.10$ \\
\hline 19 & $4.64 \pm 0.11$ & $5.06 \pm 0.07$ & $4.89 \pm 0.06$ \\
\hline 24 & $5.21 \pm 0.09$ & $5.53 \pm 0.10$ & $5.02 \pm 0.06$ \\
\hline
\end{tabular}

*Different superscript represents the significant difference within treatment in this study $(\mathrm{p}<0.05)$
The results of Anova test of biofloc protein content on day 9, day 14, day 19 and day 24 showed a significant difference $(p>0,05)$ to ratio of protein content of biofloc between treatments. Treatment B showed the highest protein content compared to treatment $\mathrm{A}$ and treatment $\mathrm{C}$. Treatment $\mathrm{C}$ (without probiotics) showed the lowest protein content results from the first week to the fourth week. Fat test results showed the highest final value obtained at treatment B.

\subsubsection{Ratio $C: N$ and $N: P$ Waters}

The ratios $\mathrm{C}: \mathrm{N}$ and $\mathrm{N}: \mathrm{P}$ waters are presented in the following table:

Table 3. The ratio of $\mathrm{C}$ to $\mathrm{N}$ and $\mathrm{N}$ to $\mathrm{P}$ in water

\begin{tabular}{cccc}
\hline \multirow{2}{*}{ Days } & \multicolumn{3}{c}{ The ratio of C to N } \\
\cline { 2 - 4 } & $\mathbf{A}$ & $\mathbf{B}$ & $\mathbf{C}$ \\
\hline 0 & 28.03 & 28.03 & 28.03 \\
9 & $27.81^{\mathrm{c}} \pm 1.37$ & $28.73^{\mathrm{b}} \pm 1.20$ & $37.67^{\mathrm{a}} \pm 3.02$ \\
14 & $18.22^{\mathrm{b}} \pm 1.02$ & $18.91^{\mathrm{a}} \pm 0.69$ & $14.60^{\mathrm{c}} \pm 0.88$ \\
19 & $5.70^{\mathrm{a}} \pm 0.10$ & $5.00^{\mathrm{c}} \pm 0.09$ & $5.24^{\mathrm{b}} \pm 0.13$ \\
24 & $2.34^{\mathrm{a}} \pm 0.39$ & $2.07^{\mathrm{b}} \pm 0.33$ & $2.05^{\mathrm{c}} \pm 0.04$ \\
\hline \multicolumn{4}{c}{ The ratio of N to $\mathbf{P}$} \\
\hline \multirow{4}{*}{ Days } & $\mathbf{A}$ & $\mathbf{B}$ & $\mathbf{C}$ \\
\cline { 2 - 4 } & 38.12 & 38.12 & 38.12 \\
9 & $23.08^{\mathrm{a}} \pm 0.08$ & $23.23^{\mathrm{a}} \pm 0.07$ & $23.51^{\mathrm{a}} \pm 2.31$ \\
14 & $47.49^{\mathrm{c}} \pm 1.07$ & $47.65^{\mathrm{b}} \pm 0.39$ & $104.80^{\mathrm{a}} \pm 8.79$ \\
19 & $73.03^{\mathrm{c}} \pm 0.82$ & $93.10^{\mathrm{b}} \pm 0.95$ & $117.87^{\mathrm{a}} \pm 4.18$ \\
24 & $35.86^{\mathrm{c}} \pm 0.31$ & $41.92^{\mathrm{b}} \pm 0.41$ & $102.56^{\mathrm{a}} \pm 2.60$ \\
\hline
\end{tabular}

*Different superscript represents the significant difference within treatment in this study $(\mathrm{p}<0.05)$

$\mathrm{A}$ : treatment using probiotic $\mathrm{A}$

$\mathrm{B}$ : treatment using probiotic $\mathrm{B}$

$\mathrm{C}$ : without probiotic

The C:N ratio increased from day 0 to day 9 , then decreased drastically on day 14 and continued to decline until day 24 . On day 9, the highest $\mathrm{C}: \mathrm{N}$ ratio was found in treatment $\mathrm{C}$ (37.67), followed by treatment B (28.7) and last on treatment A (27.81). The C:N ratio continued to decline until day 24, and the Anova results show that the treatment was significantly different. The highest value of $\mathrm{C}: \mathrm{N}$ ratio was found in treatment $\mathrm{A}$ (2.34), followed by treatment B (2.07) and, finally, treatment C (2.05). The ratio of $\mathrm{N}: \mathrm{P}$ at the beginning to the end of the study was fluctuated. The N:P ratio of all treatments decreased from day 0 to day 9 . The N:P ratio on all 14 th and 19 th day treatments increased and again decreased on day 24. The ratio of $\mathrm{N}: \mathrm{P}$ continued to increase until the 19th day with the highest value at treatment $C$ (117.87) followed by treatment B (93.10) and finally treatment A (73.03), with different treatments. On day 24 the $\mathrm{N}: \mathrm{P}$ ratio decreased, with the highest value in treatment C (102.56), followed by treatment B (41.92) and then treatment A (35.86) with different treatments. 


\subsection{Discussion}

Protein and fat content of biofloc produced from treatment A, treatment B and treatment C on day 9, day 14, day 19 and day 24 showed an increase in all observed days. This can be seen from the Anova test results, which showed that there were no significant differences $(p>0.05)$ on the ratio of protein and fat content in the formed biofloc between those treatments. Moreover, treatment B showed the formed biofloc with higher average protein content than treatment $\mathrm{A}$ and treatment $\mathrm{C}$. The protein content during the research was lower than the biofloc standard protein formation, despite increase in each week. According to the research conducted by [6], the nutrient content of biofloc grown on pisciculture water media accounted for $37.37 \%$ in protein and $11.88 \%$ in fat, which is higher than the results of this research.

The higher protein content of treatment $\mathrm{B}$ than treatment $\mathrm{A}$ treatment was due to the use of $\mathrm{CaCO}_{3}$ and $\mathrm{C}$ treatment without lime, which indicated to be affected by the elements of $\mathrm{Mg}$ in dolomite. The limestone dolomite has the chemical formula of $\mathrm{CaMg}\left(\mathrm{CO}_{3}\right)_{2}$. Moreover, dolomite disposals can be increase the availability of elements $\mathrm{Ca}, \mathrm{Mg}$ and $\mathrm{P}$. Some minerals are an enzyme activator for assisting the microbial metabolism, such as $\mathrm{Mg}^{2+}, \mathrm{Ca}^{2+}, \mathrm{Mn}^{2+}$ and other. Magnesium serves as a cell cation that is important as a protease enzyme cofactor. Magnesium is regulated by adenosine triphosphat (ATP) in mitochondrial for protein synthesis in the heart. The ATP is an energy molecule to provide almost the entire metabolic process and is mainly formed as a complex with magnesium (Mg-ATP). Magnesium regulates a number of stages during the synthesis of nucleic acids (DNA, RNA and protein). However, Mg deficiency can decrease the bacteria protein synthesis.

Protein content in the formed biofloc came from the bacteria that grew on the medium. This is in line with the results of the N:P ratio in the biofloc media, which ranged from $35.86 \mathrm{mg} / \mathrm{L}$ to $102.52 \mathrm{mg} / \mathrm{L}$ [7]. According to [8], N:P ratios above 20 cause the dominant bacterial populations in biofloc media, which demonstrates that there is higher abundance of nitrogen concentrations in water than phosphorus. This results in the growth of blue-green algae, and dinoflagellates, chlorella and diatomae become limited. The statement is also in line with the results of the density and diversity of plankton that was steadily declining at the end of the study, meaning that more bacteria dominate the biofloc media than plankton [9].

The content of total $\mathrm{N}$ and $\mathrm{P}$ increased in the early formation of floc until the end of the study [7]. This is due to the diversity and density of plankton being low [9], so that the $\mathrm{N}$ and $\mathrm{P}$ is underused by plankton for metabolic processes. Nitrogen and phosphate are abundant in water, which indicates that the nutrient is underused by phytoplankton, thus making the possibility of growing phytoplankton no long er existed, but, in turn, the heterotrophic bacteria form the floc instead. $\mathrm{N}$ content in the early formation of floc ranged from $0.74 \mathrm{mg} / \mathrm{L}-1.14 \mathrm{mg} / \mathrm{L}$ and at the end of the study from $70.167 \mathrm{mg} / \mathrm{L}-90.155 \mathrm{mg} / \mathrm{L}$, while the $\mathrm{P}$ content in the early formation of floc ranged from $0.03 \mathrm{mg} / \mathrm{L}-0.05 \mathrm{mg} / \mathrm{L}$ and at the end of the study at $0.68 \mathrm{mg} / \mathrm{L}$ $2.15 \mathrm{mg} / \mathrm{L}$.

Nitrogen is an ingredient needed by bacteria, especially for the synthesis of amino acids and nucleotides. Sources of nitrogen may be derived from organic and inorganic sources.
Sources of organic matter are usually obtained by the bacteria in the culture system found in residual feed and shrimp metabolite derivation. Protein contained in the remaining feed will be decomposed by bacteria using protease enzymes into amino acids and are eventually assimilated into the bacterial cells [10].

The inorganic nitrogen can be converted into single cell protein with the addition of carbon materials waters and used as feed for fish and shrimp [11]. The addition of carbon can improve the assimilation of $\mathrm{N}$ by bacteria, which implies the reduction of the amount of ammonia that can support microbial protein biosynthesis [10]. The source of carbon (C) used in this research was molasses, which was given at the beginning of treatment.

The ratio of $\mathrm{C}: \mathrm{N}$ and $\mathrm{N}: \mathrm{P}$ waters were tested at the beginning and when the floc was first formed on day 9 until the end of the research. This is consistent with the results of research that the floc started to form after six days of culture. According to [12], the emergence of floc is characterized by a color change of the media from clear to brown accompanied by the emergence of bubbles.

$\mathrm{C}: \mathrm{N}$ ratio in all treatments showed that the $\mathrm{C}: \mathrm{N}$ ratio continued to decline from day 9 and formed floc up to day 24 . The increase in $\mathrm{N}$ content was higher than the increase in $\mathrm{C}$ content, generating the value of $\mathrm{C}: \mathrm{N}$ ratio which becomes declined from the beginning to the end of the study. Anova test results showed no significant differences $(p<0.05)$ to the $C: N$ ratio biofloc media between treatments.

$\mathrm{C}: \mathrm{N}$ ratio on the first day of floc growth figures showed over 20, both in treatment A, B and C. C:N ratio reached its highest on day 9 , which was obtained in treatment $C$, which is the control. This is in accordance with the opinion of [4] that, in order to form biofloc quickly, the $\mathrm{C}: \mathrm{N}$ ratio needs to be maintained at a ratio of $20: 1$. Furthermore, the $C: N$ ratio is increasingly down ranged from 2.05 to 2.34 , which is suspected to be because the increased content of $\mathrm{C}$ is not comparable with the rapid increase in the content of $\mathrm{N}$. The decrease of $\mathrm{C}: \mathrm{N}$ ratio is due to the addition of ZA fertilizer every 10 days which was not coupled with the addition of molasses as a source of $\mathrm{C}$. The value of $\mathrm{N}$ was high also because the result of an overhaul of inorganic $\mathrm{N}$ in surface waters. This is in accordance with the opinion of [13], which states that the ratio $\mathrm{C}: \mathrm{N}$ is low, which shows the process of decomposition by bacteria works quickly to produce large $\mathrm{N}$. This results in a high total $\mathrm{N}$ content in the water.

The ratio of $\mathrm{N}: \mathrm{P}$ in all treatments continued to increase from day 9 of floc formed until day 19 and then decreased on day 24. Despite the decline, the ratio of N:P on day 24 was still high and ranged $35.86-102.52$. According to [5], the ratio of $\mathrm{N}: \mathrm{P}>12$ ( $\mathrm{P}$ as a limiting factor), while the ratio of $\mathrm{N}: \mathrm{P}<7(\mathrm{~N}$ as a limiting factor). The ratio of $\mathrm{N}: \mathrm{P}$ was high, allegedly due to the increase in $\mathrm{N}$ content, which was comparable to the increase in the content of the framework of [7], who identified that the $\mathrm{N}$ and $\mathrm{P}$ were very abundant in the water due to being less utilized by phytoplankton. This is because of the possibility that content in the water is no longer phytoplankton, but heterotrophic bacteria, which turns to form floc. The results of this research indicated that the ratio of $\mathrm{N}: \mathrm{P}$ in all treatments was more than 20. According to [8], generally, if the ratio of $\mathrm{N}: \mathrm{P}$ is more than 20 , then the bacterial population will be dominant. 
Dominant heterotrophic bacteria which grows in the formed floc made the protein content of the biofloc in this research increasingly higher than the protein content at baseline of the water (in the range of 20.51 to $25.59 \%$ ) [14]. This is in accordance with the opinion of [15], that the organic material is more quickly converted into protein by heterotrophic bacteria than the phytoplankton. Bacteria decompose the organic substrates for growth and energy as well as the use of ammonium for protein synthesis [16]. Although protein biofloc in this research was higher [14], the content amount of protein was not optimum, because that biofloc dominated by bacteria and green microalgae protein was dramatically higher $38 \%$ and $42 \%$ protein). The low protein content in this research was due to the diversity of phytoplankton being gained much lower [9].

\section{Conclusion}

The conclusions that can be presented from this research are that different probiotic significantly affected biofloc nutrition and the most protein and fat content was obtained from probiotic B.

\section{Acknowledgment}

Thanks to Faculty of Fisheries and Marine Universitas Airlangga for The Annual Research Grant through Rencana Kerja Anggaran Tahunan (RKAT) for Research Scheme 2016.

\section{References}

[1] Aiyushirota. 2009. Shrimp Culture Concepts Heterotrophic Bacteria System with Bioflocs. Science Articles. Page 2-5.

[2] Avnimelech, Y. 2007. Feeding with Microbial Flocs by Tilapia in Minimal Discharge Bio-flocs Technology Ponds.Aquaculture. 264:140147.

[3] Brune, D.E., G. Schwartz, A.G. Eversole, J.A. Collier and T.E. Schwedler. 2003. Intensification of Pond Aquaculture and High Rate Photosynthetic. Aquaculture Engineering. 28:65-86.

[4] Gunarto dan H.S. Suwoyo. 2011. Produksi Bioflok dan Nilai Nutrisinya dalam Skala Laboratorium. Balai Riset Perikanan Budidaya Air Payau. hal 1009-1017.
[5] Indrayani, E., K.H. Nitimulyo, S. Hadisusanto dan Rustadi. 2015. Analisis Kandungan Nitrogen, Fosfor dan Karbon Organik di Danau SentaniPapua. Jurnal Manusia dan Lingkungan. 22(2): 217-225.

[6] Jalasari, S.B. 2016. Pengaruh Pemberian Jenis Kapur yang Berbeda terhadap Kandungan Protein Bioflok.Fakultas Perikanan dan Kelautan. Universitas Airlangga. Surabaya. (belum diterbitkan).

[7] Purnomo, P.D. 2012. Pengaruh Penambahan Karbohidrat pada Media Pemeliharaan terhadap Produksi Budidaya Intensif Nila (Oreochromis niloticus). Journal of Aquaculture Management and Technology. 1(1): 161-179.

[8] Puspitasari, I. 2016. Pengaruh Pemberian Jenis Kapur Berbeda terhadap RasioC:N dan N:P Media Bioflok. Skripsi. Program Studi Budidaya Perairan. Fakultas Perikana dan Kelautan. Universitas Airlangga. Surabaya. 87 hal. (belum diterbitkan).

[9] Rangka, N.A. dan Gunarto. 2012. Pengaruh Penumbuhan Bioflok pada Budidaya Udang Vaname Pola Intensif di Tambak. Jurnal Ilmiah Perikanan dan Kelautan. 4(2):142-145.

[10] Ruliaty, L., M. Soleh dan A. Nur. 2012. Pemanfaatan Teknologi dalam Pemeliharaan Benih Bandeng Chanos chanos F. Jurnal Balai Besar Pengembangan Budidaya Air Payau Jepara. hal 1-10

[11] Sari, M. 2016. Pengaruh Pemberian Jenis Kapur yang Berbeda terhadap Keragaman dan Kepadatan Plankton Air Tawar pada Media Kultur Bioflok. Fakultas Perikanan dan Kelautan. Universitas Airlangga. Surabaya. (belum diterbitkan).

[12] Sari, N.P. 2012. Komposisi Mikroorganisme Penyusun dan Kandungan Nutrisi Bioflok dalam Media Pemeliharaan Induk Ikan Nila Oreochromis niloticus dengan Aplikasi Teknologi Bioflok (BFT). Skripsi. Fakultas Perikanan dan Ilmu Kelautan. Institut Pertanian Bogor. Bogor.

[13] Sukenda, Hadi, P. dan Harris, E. 2006. Pengaruh Pemberian Sukrosa sebagai Sumber Karbon dan Probiotik terhadap Dinamika Populasi Bakteri dan Kualitas Air Media Budidaya Udang Vaname (Litopenaeus vannamei). Jurnal Akuakultur Indonesia. 5(2):179-190.

[14] Usman. 2012. Konversi Limbah Nitrogen Budidaya Ikan Menjadi Bioflok dan Pemanfaatannya Bagi Pertumbuhan Ikan Bandeng. Tesis. Program Pasca Sarjana. Institut Pertanian Bogor. Bogor. 194 hal.

[15] Vrananta, S.D., P. Soedarsono dan N. Afiati. 2013. Hubungan Nisbah C:N dengan Jumlah Total Bakteri pada Sedimen Tambak di Areal Balai Besar Pengembangan Budidaya Air Payau, Jepara. Journal of Management of Aquatic Resources. 2(3):265-272.

[16] Yuniawati, M., F. Iskarima dan A. Padulemba. 2012. Optimasi Kondisi Proses Pembuatan Kompos dari Sampah Organik dengan Cara Fermentasi Menggunakan EM4. Jurnal Teknologi. 5 (2): 172-181. 